\title{
MEMAHAMI YOHANES 14:1-14 DENGAN TINJAUAN EKSEGETIS SOSIAL-SAINTIFIK
}

\author{
Nurliani Siregar ${ }^{1}$, Sukanto Limbong ${ }^{2}$, \\ Dominggus Pote ${ }^{3}$, Hasahatan Hutahaean \\ Universitas HKBP Nommensen ${ }^{1}$, Sekolah Tinggi Teologi HKBP², \\ Sekolah Tinggi Teologi Saint Bandung ${ }^{3}$, Sekolah Tinggi Teologi Sumatera Utara ${ }^{4}$ \\ hasea2014@gmail.com*
}

\begin{abstract}
This study aims to understand John 14:1-14 by using the social-scientific exegetical method. The research prioritizes historical review and explanation of historical writings on the Way and the Truth and Life from the Old Testament (OT) to New Testament (NT) times. Jesus as the way, the truth, and the life in the face of today's postmodern relativism. The results of the study conclude that "Jesus is life (eternal)" and "Jesus is the truth" where the Church and the people of Jesus (the Church) can dialogue and apply the relative truth in love, justice, and social liberation.
\end{abstract}

Keywords: hermeneutic; John 14; socio-scientific

Abstrak. Penelitian ini bertujuan memahami Yohanes 14: 1-14 dengan menggunakan metode eksegetis sosial-saintifik. Penelitian mengutamakan tinjauan historis dan eksegese terhadap karya penulisan-penulisan sejarah mengenai Jalan dan Kebenaran dan Hidup sejak zaman Perjanjian Lama (PL) hingga zaman Perjanjian Baru (PB). Yesus sebagai jalan, kebenaran, dan hidup dalam rangka menghadapi relativisme postmodern zaman ini. Hasil penelitian menyimpulkan bahwa "Yesus adalah hidup (kekal)", dan "Yesus adalah kebenaran" di mana gereja dan umat Yesus (Gereja) mampu berdialog dan menerapkan kebenaran relatif di dalam kasih, keadilan dan pembebasan sosial.

Kata kunci: hermeneutika; Yohanes 14; sosial-saintifik

Pencarian makna teks/eksegese $(\varepsilon \xi \eta \gamma \varepsilon o \mu \alpha \iota$ exēgeomai $=$ Yunani $)$

yang berarti "membawa keluar" atau "membaca keluar" makna teks adalah proses dari tugas "membawa antara" (memperantarai/menghubungkan) pemaknaan orang dahulu kepada masa sekarang. Di dalamnya terdapat interaksi dengan bahasa asli melalui penggunaan hermeneutik dengan pandangan pengaplikasian teks terhadap gereja dan dunia masa kini (Bock, 2006). Pada akhirnya, hal utama dari eksegese adalah untuk mengerti pesan teks. 
Penelitian historis mendekati teks sebagai hasil karya historis dan penelusuran terkait dengan bagaimana memahami konteks peristiwa teks menjadi fokus. Penelitian teologis menghargai teks teks sebagai produk cara berpikir teologis dari para penulisnya. Ketiga cakupan penelitian di atas membutuhkan suatu pendekatan baru yang lebih progresif terhadap konteks sosiologis teks dan konteksnya. Rainer mensinyalir bahwa pendekatan eksegesis sosial semakin gencar dalam 30 tahun terakhir karena adanya gejolak sosial di beberapa Negara terhadap pemahaman Alkitab (Baca. Rainer, 2012). Teks yang mempunyai pesan bagi para pembacanya itu sendiri haruslah dimengerti sebagai produk dari sebuah dunia sosial dan berusaha untuk mendorong pembaca memasuki dan melampaui cara pandang terhadap dunia (world-view) tersebut (Osborne, 2012). Bahkan menurut Elliot, perkembangan metode eksegese telah dipengaruhi oleh keyakinan bahwa tujuan penafsiran Alkitab adalah penentuan makna teks Alkitab dalam konteks aslinya melalui pengujian komprehensif terhadap semua karakter teks (dengan berbagai pola tekstual, retorikal, linguistik, historis, teologis literer, atau misalnya redaksional dan tradisional) dan berbagai elemen yang menjadi kunci untuk menemukan maknanya. Berbagai teks dan konteks tersebut menjadi latar belakangnya kemudian dan memberikan hasil yang selalu punya dimensi sosial yakni menyelamatkan umat-Nya dengan cinta-Nya (Triasmoroadi, 2018). PB mengandung kesaksian terhadap fenomena 
sosial, pengumpulan suatu komunitas Yesus dari Nazaret yang dipahami sebagai Mesias Israel dan Juru selamat masyarakat (Elliott, 1993).

Usaha menafsirkan teks Alkitab telah berkembang dengan pesat, mulai dari tipologi dan alegori sampai ke kanonikal dan historis kritis. Sejak tahun 70-an, terdapat sebuah metode tafsir baru yang sangat berkembang dengan menitikberatkan ilmu sosial. Metode ini dikenal sebagai metode tafsir sosial saintifik (social-scientific method of interpretation) (Arbiol, 2004). Metode ini sebenarnya merupakan pengembangan dari metode historis kritis, sehingga hal-hal mendasar dalam historis kristis seperti kritik teks, redaksi, sumber, dll. Tetap dipakai dengan menambahkan pendekatan ilmu sosial secara khusus dengan model-model yang tepat.

Penggunaan sosial saintifik pada proses eksegesis memberikan pemahaman dan cara pandang yang komplit karena sisi kehidupan yang ada di sekitar kejadian terungkap bagi pembaca. Memperhatikan mengapa satu perumpamaan (misalnya) menggunakan lima gadis bijak atau penggunaan sistem tanam tentu akan dapat dipahami jika menelusuri sejarah penggunaan kegiatan itu secara lengkap.

Salah satu kitab yang kerap dianggap sangat menekankan pesan teologis reflektif dari kehidupan Yesus adalah Injil Yohanes. Injil ini dianggap berpusat bukan pada kesejarahan dan peristiwa peristiwa yang dilakukan Yesus, tetapi pada makna rohani/teologis dari peristiwa tersebut. Para ahli PB menganggap bahwa Injil Yohanes adalah suatu 
penafsiran teologi abad kedua tentang kehidupan Yesus dengan memakai bahasa dan bentuk-bentuk pemikiran filsafat Helenis (Harming, 2017). Padahal, Injil Yohanes pun sebenarnya ditulis sebagai suatu respons sosial dari apa yang tercantum dalam Yohanes 20:31 "semua yang tercantum disini telah dicatat, supaya kamu percaya, bahwa Yesuslah Mesias, Anak Allah". Tujuan penulis Injil ini adalah untuk melahirkan iman (20:30-31) dan dengan pemikiran ini dia membentuk kesaksiannya berdasarkan kebutuhan para pembacanya (Carson \& Moo, 2006) yaitu para pembaca yang punya latar belakang sosial tertentu.

Salah satu teks yang menarik dalam Injil Yohanes untuk dikaji berdasarkan metode ini adalah perihal kesadaran diri Yesus sebagai jalan, kebenaran dan hidup. Keseluruhan teks Yohanes 14:1-14 menyiratkan suatu paradigma teologis tentang siapa Yesus secara praeksistensial, historis, dan fungsional. Pasal ini - yang diawali dengan janji akan hidup masa depan dimana para murid akan bersama sama dengan Yesus (ayat 1-4) - berisikan jawaban Yesus atas pertanyaan Tomas tentang "jalan" kemana Yesus akan pergi (ayat 5-7). Jawaban Yesus ini membuahkan permintaan baru dari Filipus supaya Bapa dinyatakan (ayat 8-14) (Lihat Larcher et al., 2010). Pernyataan-Nya sebagai jawaban atas pertanyaan Tomas - di dalam Yohanes 14:6 dalam transliterasi tertulis egō eimi hē hodos kai hē alētheia kai hē zōē = Aku adalah jalan dan kebenaran dan hidup (LAI-TB) menunjukkan semacam kesadaran diri. Yesus menyadari diri-Nya sebagai jalan, kebenaran dan hidup. Secara 
sosial-saintifik, kesadaran diri Yesus ini mengandung makna yang mendalam. Secara sosial-saintifik, bagi Richard L. Rohrbaugh, kesadaran diri dalam konteks Yesus sejarah adalah sesuatu yang tidak tepat, bukan karena itu tidak terjawab, tetapi karena secara kultural bersifat etnosentris. Semua pertanyaan tentang kesadaran diri Yesus harus dikaitkan dengan kelompok sosial di sekitarnya (Band. Rohrbaugh, 2002). Artinya, memahami kesadaran diri Yesus sebagai jalan, kebenaran dan hidup haruslah mempertimbangkan apa yang para murid dan masyarakat pahami tentang diri-Nya.

Pernyataan selanjutnya dalam ayat yang sama lebih kontroversial. Transliterasi pada ayat berikut yakni oudeis erchetai pros ton patera ei me di emou (tidak seorang ada seorang pun yang datang kepada Bapa, kalau tidak melalui Aku = LAI-TB) merupakan pernyataan yang banyak digugat dalam dunia post modernisme dewasa ini atas ekslusivitas Yesus sebagai jalan, kebenaran dan hidup, terutama oleh mereka yang menganut pluralisme. Ekslusivisme menekankan normativitas Yesus yang menentukan keselamatan (Adiprasetya, 2014). Kekristenan dianggap sebagai agama yang benar karena menerima kasih Allah dalam Kristus (Adiprasetya, 2002). Tokohnya seperti Karl Bath, sebagaimana dikutip Adiprasetya, misalnya menganggap bahwa pernyataan dan keselamatan diberikan hanya di dalam Yesus Kristus (Adiprasetya, 2002). Sementara Hendrik Kraemer menyatakan bahwa dasar satu-satunya adalah iman bahwa Allah telah menyatakan 'Jalan dan Kebenaran dan Hidup' dalam 
Yesus Kristus dan kemauan untuk dikenal oleh seluruh dunia. Meskipun sama-sama eksklusivis dengan Karl Barth, tapi Kraemer lebih mendekatinya bukan secara a priori, tetapi a posteriori dengan menekankan bahwa pernyataan dalam pengertian hukum moral terdapat dalam agama agama lain, tetapi keselamatan hanya dalam Yesus.

Pluralisme sendiri, yang melawan eksklusivisme, berpusat pada universalitas kasih Allah bagi dunia. Kristus bukanlah satu satunya jalan keselamatan (Adiprasetya, 2002). Cantwell Smith, salah seorang penganut pluralisme, sebagaimana dikutip Newbigin mengatakan "Allah tidak dinyatakan secara penuh dalam Yesus Kristus kepada saya, atau kepada siapapun yang lain yang saya sudah temui" (Newbigin, 1993, 231). Bahkan klaim eksklusif disebutnya sebagai berhala, karena tidak ada agama yang sempurna mengenai Allah (Ginting, 2018).

Di sisi lain, Hick menyebut Yesus sebagai totus dues (sepenuhnya Allah) dalam pengertian agape-Nya sungguh sungguh adalah Agape Allah yang bekerja di bumi, namun la bukan totum dei (keseluruhan Allah). Melihat hal tersebut, metode historis kritis yang telah berkembang dikalangan para ahli harus diperlengkapi dengan pendekatan baru guna memahami Alkitab sebagai produk dan jawaban terhadap lingkungan sosial budaya. Pendekatan ini disebut kritik sosial-saintifik (sosial-sains). Kritik sosial-saintifik ialah suatu pengembangan, bukan pengganti terhadap metode yang telah ada dan lebih dikenal yakni historis kritis. Elliot menyatakan bahwa kritik sosial-saintifik dapat dinyatakan untuk 
melengkapi usaha eksegese sub disiplin lainnya dengan penekanan sub satansi pada dimensi sosial teks, konteks penulisan dan penerimaannya, dan inter relasi mereka (Elliott, 2005). Metode sosial-saintifik tidak dapat dipersamakan dengan "antropologi atau sosiologi Alkitab". Malah, model ini mempertemukan sains sosial yang terdiri dari sosiologi, antropologi, psikologi, politik dan geografi dengan eksegese sebagai suatu penggabungan dari sisi teologis, historis, literer, maupun sosial-saintifik. Metode ini berfokus pada penentuan apa yang penulis katakan dan maksudkan lewat perkataannya kepada para orang sezamannya. Makna teks ditentukan oleh sistem sosial (Elliott, 1993). Pendekatan ini tidak mengabaikan pesan teologis, tapi justru memperkaya dengan memberikan informasi tentang tujuan penulisan teologi teks maupun implikasi sosial yang ada dibaliknya. Pada metode eksegesis social saintifik, diperlukan mengungkap situasi sosial yang dilihat secara utuh untuk memperkuat hasil penggalian (eksegesis) (Hays, 2021) sehingga pemahaman pembaca sekarang lebih lengkap.

Berdasarkan Eksegetis Sosial-Saintifik yang menjadi latar belakang, maka penulis tertantang untuk meneliti tulisan ini menjadi suatu penelitian teologis eksegetis dengan judul: "Jalan Dan Kebenaran Dan Hidup" Dan Subjudul: "Suatu Tinjauan Eksegetis Sosial-Saintifik Yohanes 14:1-14." 


\section{METODE}

Bagi Denzin dan Lincoln yang termasuk metode kualitatif meliputi penggunaan dan pengumpulan beraneka ragam data empiris yang sedang dipelajari di antaranya analisa teks, historis serta mencari makna dalam kehidupan individu (Denzin \& Lincoln, 2011). Untuk menggali judul di atas metode penafsiran sosial-saintifik dengan penelitian kepustakaan (library research). Metode ini termasuk pada pendekatan kualitatif, di mana lebih menyentuh ke humaniora, ilmu-ilmu sosial dan ilmu-ilmu fisik (Hamzah, 2019). Metode penelitian kepustakaan mengubah lapangan menjadi ruang perpustakaan dan mengambil porsi analisa teks dan wacana lebih dominan (Hamzah, 2020).

Bagi Burlian, ilmu sosial yang dimaksud mencakup sosiologi, antropologi, psikologi, ilmu politik, ilmu ekonomi, dan geografi (Burlian, 2020). Demikianlah penggunaan ilmu sosial ini dalam ilmu tafsir Alkitab disebut sebagai kritik sosial saintifik yang secara jelas disebut Elliot sebagai fase tugas eksegetis yang menganalisis dimensi sosial dan budaya dari perspektif, teori, model, dan penelitian ilmu-ilmu sosial (Elliott, 1993). Karena tidak mungkin menggunakan semua teori dan model dari ilmu sosial, maka penulis hanya akan menggunakan model-model ilmu sosial yang tepat untuk menjelaskan teks Yohanes 14:1-14. Adapun langkah-langkahnya pertama menjelaskan metode penafsiran sosialsaintifik. Kedua, menggali konteks sosial dari teks Yohanes 14:1-14. Dan ketiga mengungkap makna yang terdapat di dalam teks. 


\section{HASIL}

Injil Yohanes tidak menamai penulisnya. Bagaimanapun, kehadiran penulis dalam Injil ini dirasakan melalui acuan" murid yang dikasihi”, yang diidentifikasi oleh tradisi gereja mula-mula sebagai Yohanes anak Zebedeus (deSilva, 2000), (lih Yoh. 13:23; 19;26; 21:7; 21:20; terutama 21:24 "Dialah murid, yang memberi kesaksian tentang semua ini dan yang telah menuliskannya dan kita tahu, bahwa kesaksiannya itu benar. Sementara itu, dalam pasal 21-dimana murid yang dikasihi diceritakan kemungkinan besar menunjukkan bahwa dia adalah salah satu dari yang disebutkan dalam 21:2 yaitu Simon Petrus, Tomas yang disebut Didimus, Natanael dari Kana yang di Galilea, anak-anak Zebedeus dan dua orang murid-Nya yang lain. Karena itu, pertanyaan tentang siapa penulis Yohanes kebanyakan adalah usaha menjawab siapa murid yang dikasihi tersebut. Telah disebutkan diatas, Injil ini ditulis sezaman dengan fase kedua komunitas Yohanes yang menulis Injil Yohanes memiliki dilematika sejauh Injil ini dianggap berminat pada konteks lokal tertentu. Mengutip Brown, deSilva menyatakan bahwa komunitas ini hidup di Palestina, yang berselisih dengan orang Yahudi non Kristen (deSilva, 2000). Alasannya beragam. Sejak penemuan naskah Qumran, praduga ini menjadi kuat. Kesamaan beberapa teks Yohanes yang berseru di padang gurun" (1:23) sangat kentara dalam teks Qumran (Pfitzner, 1988) yang merupakan warisan Yahudi. Tentu komunitas Qumran dikenal di Palestina, bukan di 
luar Palestina. Penulis yang merupakan komunitas Yohanes pastilah mengenal tradisi Qumran karena dia hidup di Palestina.

Senada dengan hal diatas, Marshall berpendapat bahwa komunitas ini berkembang di Palestina Selatan, di mana teologi khas Yohanes dikembangkan dan anggota-anggotanyalah yang menghasilkan sastra Yohanes (Marshall, 1983). Kekhasan ke-Palestina-an ini dan kayahudiannya tampak dari hubungan dekat Injil Yohanes dengan alam pemikiran PL. Injil ini mengandalkan para pembaca sudah biasa dengan Alkitab Yahudi. Bagi mereka PL (mesti) memberi kesaksian mengenai Yesus (Yoh.5: 39; 1:45; 5:45-46). Jlka melihat relevansi latar Yahudi, (Beale, 2015) Injil ini mengutip secara langsung PL sebanyak 18 kali.

Tentang letak yang jelas tidak dapat dipastikan. Sidang pembaca Yahudi ini pastilah berada dalam komunitas Yahudi yang besar. Memang di zaman Perjanjian Baru diperkirakan sekitar lima juta (5.000.000) orang Yahudi tinggal di perantauan, sementara di Palestina sendiri paling-paling tiga juta (3.000.000) orang. Yahudi diaspora tinggal berserak di dunia Yunani-Romawi sebagai tukang, usahawan, pedagang, budak dan prajurit serta pegawai kecil. Sekelompok besar tinggal di Mesir, khususnya di kota Alkesandria. Kota itu malah menjadi semacam pusat kedua bagi bangsa. Juga di kota Roma tinggal sekelompok orang Yahudi yang agak besar. Hubungan antara kelompok-kelompok Yahudi dengan Yerusalem tetap erat dan lancar. Walaupun demikian, kelompok-kelompok diaspora ini umumnya menerima kebudayaan dan bahasa Yunani serta menyesuaikan 
diri, terlebih lagi di Aleksandria sehingga hampir tidak ada yang tahu bahasa Ibrani atau Aram. Semua berbahasa Yunani.

Komunitas Yohanes Yudea ini kemungkinan berekspansi dengan para petobat dari Samaria yang memperkenalkan pengharapan mesianis yang khas yang berfokus pada nabi Musa (Yoh 4). Menghadapi tantangan dari orang Yahudi, Attridge melihat bahwa orang-orang percaya komunitas Yohanes juga tersebar di Yudea dan diaspora (Attridge, 2019). Artinya, kemungkinan setelah pecah perang Yahudi yang ditandai dengan hancurnya Yerusalem tahun 70, atau juga setelah pengucilan tahun 85 melalui peraturan/kutukan dalam Delapan Belas Berkat (Shemoneh Esreh) tentang pengusiran dari Sinagoge, maka komunitas Yohanes juga berekspansi ke diaspora, khususnya ke Aleksandria.

Akhirnya bisa dikatakan bahwa komunitas Yohanes memakai bahan dari sang murid Yohanes dan merevisi Injil ini untuk dirinya sendiri di Palestina dan bagi sidang pembaca Yahudi Kristen di perantauan/Aleksandria yang juga adalah komunitas Yohanes. Kedua komunitas ini sebenarnya adalah orang-orang yang terkucil karena status "orang percaya" (o pisteu, wun, ho pisteuon). Jika komunitas Yohanes terkucil karena bangsa Yahudi non-Kristen, maka komunitas sidang pembaca di perantauan terkucil bukan hanya bangsa Yahudi non-Kristen, tetapi juga bangsa Yunani di perantauan.

Pada ayat 7-9, percakapan disini diisi dengan perkenalan dengan rasa kekeluargaan dan silsilah. Hal ini diutarakan dengan pertimbangan 
bahwa kedekatan kekerabatan atau kekeluargaan dapat menjadi jalan untuk mempererat hubungan. Dengan demikian tujuan dan maksud yang hendak disampaikan dapat dengan mudah dipercakapkan. Ferguson mencatat bahwa faktor kekerabatan, kekeluargaan atau ikatan sosial dapat menjadi awal pertobatan seseorang untuk menjadi pengikut Kristus (Ferguson, 2017) di abad mula-mula.

\section{PEMBAHASAN}

Abad XXI ditengarai sebagai zaman baru yang disebut dengan era purna modern (pos modern), yaitu suatu konsep heuristis yang mula-mula menolak memutlakkan rasio dan sains, tetapi kemudian berkembang menjadi penolakan terhadap pemutlakan apapun. Dalam paparan Jamhari, agama mulai cenderung menjadi subjek yang dihubunghubungkan dengan bidang lain misalnya ekonomi atau politik (Jamhari, 2020). Karena itu beberapa tokoh pun menganggap Yesus bukan Allah, melainkan manusia biasa yang memiliki limitasi kuasa, kehadiran dan keilahian (Oet, 16M).

Zaman ini tidak hanya melawan konservatisme dan tradisionalisme, tetapi juga saintisme dalam dunia modern. Muslih juga turut memberikan penekanan tentang zaman yang melawan banyak segmen, termasuk keilmuan itu sendiri dengan metodologi masing-masing. Yang dilawan adalah pemutlakannya, sehingga menjadi konservatif, tradisional atau 
percaya sains sama sekali tidak bertentangan dengan zaman post modern (Muslih, 2017).

Di zaman post modern ini, secara khusus di Indonesia, konteks kita adalah mencakup keberbagaian agama, kemiskinan yang parah, penderitaan manusia, ketidakadilan termasuk ketidakadilan gender, dan kerusakan ekologis. Franz Magnis Suseno mengatakan bahwa tantangan umat manusia dalam sistem global pada abad XXI mencakup peningkatan pengangguran, kemiskinan termasuk di negara industri maju, kesenjangan ekonomi internasional, kerusakan ekologi, (Singgih, 2020) terorisme, serta eksplorasi masalah etika termasuk biogenetik, biomedik, atau artificial intelligence (Raj \& Seamans, 2019). Fakta-fakta tersebut telah menjadi tantangan global. Di Indonesia sendiri, tantangan gereja mencakup masalah sekularisasi (keletihan terhadap kegiatan religius), pluralitas penghayatan keumatan, religiositas baru dengan segala bentuk dan eksesnya yang menawarkan pencarian spiritualitas, hubungan saling mencurigai antara dengan Islam, (Hutahaean, 2020) primordialisme yang menutup diri, komunalisme yang melibatkan seluruh komunitas dalam gejala-gejala konflik kekerasan, serta "kekerasan" sosial yang tampak dalam neoliberalisme yang murni mekanisme pasar dan "capai" dalam pemberian bantuan sosial bagi yang lemah (Lima, 2020).

Karena hal-hal itu adalah konteks post modern di mana gereja hidup, maka jawaban-jawaban teologi termasuk teologi misi pun harus beranjak dari pergumulan menjawab berbagai konteks tersebut. Alienasi 
dan destruktivisasi unsur absolutisme kebenaran sebagai produk cara berpikir post modernisme menghasilkan perbedaan-perbedaan mendasar dalam pendekatan terhadap konteks-konteks tersebut. Pada akhirnya, jawaban-jawaban teologi misi haruslah memperhatikan bagaimana jawaban-jawaban (pesan) Alkitab khususnya Yohanes 14:1-14 sebagai ideologi misi diinteraksikan dan direlevansikan secara langsung terhadap konteks kita.

Sebagai kebenaran, Yesus datang ke dunia (Yoh. 1:14,17). Yesus lahir dan datang ke dunia ini untuk memberitakan tentang kebenaran dan setiap orang yang berasal dari kebenaran mendengarkan suara Yesus (Yoh. 18:37). Merwe menyatakan di dalam Yesus kasih Allah terpancar dan keselamatan yang dari Bapa dipancarkan di dalam diri-Nya. Sebab Yesus lahir sebagai Anak yang hanya mengerjakan pekerjaan Bapa-Nya (Merwe, 2019). Bahkan Pilatus sendiri tidak menemukan kesalahan di dalam diri Yesus (18:38b). Yesus memberitakan kebenaran yang dari Allah supaya orang percaya kepada Yesus (Yoh. 8:40,45,46) dan masuk dalam komunitas orang percaya yang diberi kuasa supaya menjadi anak anak Allah (Yoh.1:9). Berita kebenaran apa yang Yesus sampaikan? Yohanes 17:17 menyatakan bahwa firman Allah adalah kebenaran yang menguduskan. Artinya, sebagai kebenaran misi Yesus adalah untuk menyampaikan keadaan yang sebenarnya (truthfullness) dari firman Allah.

Selain itu, karena kebenaran bersifat praktis (Yoh.3:21), maka misi Yesus adalah menjadi pola kehidupan moral yang bisa ditiru. Setiap aspek 
hidup Yesus mencerminkan kebenaran dan karenanya memberikan teladan bagi setiap orang percaya.

Hubungan antara Yesus dan Bapa digambarkan sebagai hubungan orang tua dan anak, dengan tambahan kesetiaan Yesus pada kehendak Bapa-Nya. Ayat 10-11 memberikan tekanan bahwa hubungan itu menjadi dasar kepercayaan orang lain untuk percaya bahwa Yesus dan Bapa Yahwe, yang dipercaya adalah satu.

Yesus adalah pola hidup norma dan praktik. Misi Yesus adalah menyatakan kebenaran dan pekerjaan Allah. Karenanya, setiap kehidupan, pengajaran, dan karya Yesus merupakan kebenaran. Otentisitas kebenaran dari Dia layaknya untuk dipercayai atau tidak, dapat dilihat dari kehidupan, pengajaran teologi dan karya-Nya ditengah tengah dunia (Sasongko, 2011, 121). Sebagai kebenaran, Dia berkata apa yang benar, mengajarkan apa yang benar dan melakukan/menegakkan kebenaran.

Demikianlah kesadaran diri Yesus sebagai jalan dan kebenaran dan hidup menginspirasi dan mendorong-Nya untuk mewujudkan jalan kepada Bapa di dalam diriNya sendiri, yang termaktub di dalam kebenaran (yang bersifat normatif dan praktis, yang bersifat ilahi maupun sosial) dan di dalam hidup kekal (futuris maupun presentis). Sangatlah tepat kalau Yesus, sebagai pengungkap/revealer (Bultmann, 2014) yang menyatakan Allah kepada dunia. 
Dalam Injil Yohanes, "percaya di dalam Yesus" berarti "datang padaNya," "menerima Dia" (1:12; 5:43), "mengasihiNya". Orang percaya memiliki hidup $(3: 15,36 ; 6 ; 40,47 ; 20: 31 ; 1$ Yoh. 5:13), telah pindah dari kematian kepada hidup (5:24; bnd. 8:24), dan tidak akan dihukum (3:18). Kepercayaan juga berarti penolakan terhadap dunia, artinya orang percaya berbalik dari dunia/kesalahan kepada kebenaran/Allah. Yesus telah memilih milikNya dari dunia, sehingga mereka tidak lagi

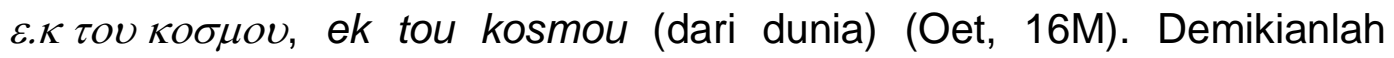
percaya dalam Injil Yohanes berarti masuk kedalam komunitas Allah atau komunitas kelompok sosial Yesus dan setia di dalamnya, bertolak belakang dengan dunia ini.

Tujuan misi adalah untuk kemuliaan Allah karena pekerjaan yang dilakukan dalam misi gereja adalah pekerjaan Allah (Mangentang \& Salurante, 2021). Kosma Manurung menerangkan bahwa karena misi berpusat pada Allah, maka kekuatan misi juga terdapat di dalam Allah dimana gereja meminta di dalam nama Yesus supaya gereja bisa melakukan misi seperti bahkan lebih besar daripada yang Yesus lakukan (Yoh. 14:12) (Manurung, 2020). Manurung menekankan bahwa satu kekuatan gereja adalah dalam pekerjaan misi. Doa menjadi kekuatan misi gereja yang di dalamnya Roh Kudus membimbing, menolong dan menghiburkan gereja di dalam misinya (Yoh.14:16, 17,26).

Esensi misi gereja berdasarkan Yohanes 14:1-14 adalah menyaksikan Yesus sebagai jalan sehingga orang datang kepada Bapa 
dan itu berarti menampakkannya di dalam kebenaran dan hidup. Menyaksikan kebenaran berarti menyatakan kebenaran paripurna Yesus di dalam kebenaran kebenaran etis gereja. Dalam hal ini, sikap dialogis dengan orang lain termasuk umat beragama lain bersama sama diarahkan kepada kebenaran paripurna etis praktis Yesus yang tampak dalam karya sosiologis, antropologi, politik, dan lain sebagainya. Menyaksikan hidup berarti menyatakan hidup kekal dengan mengundang orang untuk percaya kepada Yesus sebab siapa yang percaya akan mendapat hidup kekal.

Hidup kekal yang dimaksud memang bersifat futuris dalam kepenuhannya. Namun, hidup kekal itupun telah dinikmati di dalam persekutuan kelompok Yesus/orang percaya dengan norma etis yang disebut sebagai kasih. Memiliki keyakinan dasar dalam diri kepada konsepsi hidup sebagai hidup kekal tersebut, maka dengan sendirinya akan berpadanan pada Yesus serta hidupnya menjadi saksi di dunia ini. Dengan harapan dan kegiatan mengundang orang lain mengenal Yesus dan percaya kepada-Nya. Istilah misi untuk ini biasanya disebut sebagai pengInjilan/evangelisme. Kata pengInjilan berasal dari kata Yunani euangelizomai yang artinya membawa atau menyampaikan euangelion yaitu kabar baik dan kabar baik itu adalah proklamasi Yesus dan bahwa Dialah Yang memproklamasikan kabar baik itu. Mamahit menekankan bahwa gerakan pengInjilan memberikan pembedaan yang jelas antara wahyu umum dan wahyu khusus (Mamahit, 2020). Mengutip J.I. Packer, Waharman juga menyatakan bahwa pengInjilan tidak berfokus pada hasil, 
tetapi pada kesetiaan dalam pemberitaan Injil. Seseorang harus tetap mengupayakan pekabaran Injil, meski orang lain belum tentu menerima kabar baik itu (Waharman, 2019).

Karena penginjilan/proklamasi Injil terbuka pada pekerjaan Allah dan menghargai keputusan manusia, maka segala "kedok" dan cara cara pemaksaan secara kasar maupun lembut dapat dihindari. Pekerjaan pengInjilan memang selalu dekat dengan isu kristenisasi, sebuah istilah tidak benar khususnya bagi kalangan Injlii, karena merupakan hasil multi tafsir (Siahaan, 2017). Tapi, bagaimanapun pemberitaan Injil haruslah suatu kabar sukacita, suatu undangan terhadap manusia fana supaya percaya kepada Yesus dan mendapat hidup kekal tanpa ada paksaan.

\section{KESIMPULAN}

Yohanes 14:6 merupakan pernyataan kesadaran diri Yesus yang dapat dipertanggung-jawabkan sebagai ucapan Yesus dari kesaksian asli orang yang dekat dengan Yesus yaitu Penatua Yohanes. Kesadaran diri Yesus ini ternyata adalah kesadaran misiologis yaitu kesadaran diri sebagai jalan dan kebenaran dan hidup. Kebenaran dan hidup adalah penanda/penunjuk bagi identitas jalan itu. Karena Yesus kebenaran dan hidup adalah kebenaran dan hidup itu, maka Yesus adalah jalan kepada Bapa dan tidak ada seorang pun yang datang kepada Bapa tanpa melalui Dia. Kesadaran diri Yesus ini ternyata adalah kesadaran misiologis yaitu kesadaran untuk bermisi di dunia dengan melakukan pekerjaan Bapa. 
Sebagai jalan kepada Bapa, Dia berperan sebagai kebenaran dan hidup. Yesus menunjukkan diri-Nya sebagai jalan kepada Bapa dengan berlaku dengan berlaku sebagai kebenaran dan hidup. Sebagai kebenaran, Yesus menyadari diri-Nya benar dalam semua apa yang dikatakan dan dilakukan-Nya sebab yang Dia yakini kebenaran itu berasal dari Bapa dan mengerjakan pekerjaan Bapa. Secara sosial saintifik, Yesus menyatakan kebenaran itu dengan melakukan pembaharuan sosial dan melawan etnosentrisme Yahudi. Dengan kelompok sosial-Nya, Yesus berperan aktif dalam politik kesejahteraan, bukan demi jabatan. Sebagai hidup, Yesus menyadari diri-Nya membawa hidup kekal yang bisa dinikmati secara presentis dan futuris.

Karena gereja di sini berada dalam masyarakat timur yang kolektivis, maka gereja disarankan memiliki kesadaran diri yang kuat yang dapat dipercayai orang-orang sekitar dengan mengutamakan karyanya di dalam misi Allah supaya kemuliaan-Nya diakui didunia melalui pemberlakuan kehendak-Nya atas dunia dan hidup kekal bagi orang percaya. Gereja harus tetap mempertahankan ortodoksi yang Alkitabiah tentang persoalan partikularitas Yesus sebagai jalan, kebenaran, dan hidup dalam rangka menghadapi relativisme post modern zaman ini. Gereja dipanggil melakukan misinya yang seimbang antara proklamasi Injil dengan pembebasan sosial. Proklamasi Injil mengandung makna "Yesus adalah hidup (kekal)", sementara pembebasan sosial mengandung makna "Yesus adalah kebenaran" dimana gereja dan pemeluk agama lain 
dapat berdialog karena memiliki kepentingan kebenaran relatif di dalam kasih, keadilan dan pembebasan sosial. Misi gereja tidak boleh mengabaikan salah satu kedua dari aspek ini supaya Injil menjadi kontekstual secara holistik: proklamasi dan dialog, keselamatan rohani dan keselamatan sosial. Gereja perlu membentuk kelompok-kelompok studi dan aksi seperti kelompok sosial Yesus dalam rangka pembaharuan sosial yang aktif, dengan mempertahankan perjuangan anti kekerasan serta anti politik legal. Dengan berpartisipasi di dalam misi Allah, gereja harus mengutamakan kemuliaan Allah dengan memperkuat doa sesuai kepentingan Yesus saat di dunia.

\section{DAFTAR PUSTAKA}

Adiprasetya, J. (2002). Mencari Dasar Bersama. BPK Gunung Mulia.

Adiprasetya, J. (2014). Akulah Jalan, Kebenaran, Dan Hidup: Kemungkinan Kehadiran Kristus di dalam Agama-Agama Lain. Jurnal Amanat Agung, 10(2), 247-271.

Arbiol, C. J. G. (2004). Overvaluing the Stigma: An example of selfstigmatization in the Jesus movement (Q 14:26-27; 17:33). Biblical Theology Bulletin, 34(4), 161-166. https://doi.org/10.1177/01461079040340040401

Attridge, H. W. (2019). History, Theology, and Narrative Rhetoric in the Fourth Gospel (Pere Marquette Theology Lecture). Marquette Univ.

Beale, G. K. (2015). Buku Pedoman Penggunaan Perjanjian Lama Oleh Perjanjian Baru: Eksegesis dan Interpretasi. Literatur SAAT.

Bock, Darrell L. (2006). Opening Questions: Definition and Philosophy of Exegesis. In Darrell Land Bock \& B. M. Fanning (Ed.), Interpreting the New Testament Text: Introduction to the art and Science of Exegesis (hal. 1-32). Crossway.

Bultmann, R. (2014). The Gospel of John (Johannine Monograph), A Commentary (G. R. B. Murray (ed.)). Wipf and Stock Publisher.

Burlian, H. Z. E. (2020). IImu Alamiah Dasar, IImu Budaya Dasar, dan IImu 
Sosial Dasar (M. S. Is (ed.)). Intelegensia Media.

Carson, D. A., \& Moo, D. J. (2006). An Introduction To The New Testament. Publishing Permission Of zondervan, Grand Rapids.

Denzin, N. K., \& Lincoln, Y. S. (2011). Disiplin dan Praktik Penelitian Kualitatif. In N. K. Denzin \& Y. S. Lincoln (Ed.), The SAGE HANDBOOK Of Qualitatif Research 1 (Ketiga, hal. 1-34). Pustaka Pelajar.

deSilva, D. A. (2000). Honor, Patronage, Kinship \& Purity: Unlocking New Testament Culture. Inter Varsity Press Academic.

Elliott, J. H. (1993). What is Social-Scientific Criticism (Guides to Biblical Scholarship New Testament Series). Fortress Press.

Elliott, J. H. (2005). A Home for the Homeless: A Social-Scientific Criticism of 1 Peter, Its Situation and Strategy. Wipf and Stock Publisher.

Ferguson, E. (2017). Backgrounds of Early Christianity (Ketiga). Gandum Mas.

Ginting, E. S. (2018). Theologia Religionum (Teologi Agama-Agama). In J. S. Aritonang (Ed.), Teologi-Teologi Kontemporer (hal. 184-201). BPK Gunung Mulia.

Hamzah, A. (2019). Metode Penelitian Kualitatif. Literasi Nusantara.

Hamzah, A. (2020). Metode Penelitian Kepustakaan (Revisi). Literasi Nusantara.

Harming, H. (2017). Metode Penginjilan Yesus Dalam Injil Yohanes 4:142. Evangelikal: Jurnal Teologi Injili dan Pembinaan Warga Jemaat, 1(2), 162-169. https://doi.org/10.46445/EJTI.V1l2.73

Hays, C. M. (2021). What is the Place of My Rest? Being Migrant People(s) of the God of All the Earth. Open Theology, 7(1), 150-168. https://doi.org/10.1515/opth-2020-0154

Hutahaean, H. (2020). Tantangan Teologi Agama-agama: Suatu Diskursus Model. Kurios: Jurnal Teologi dan Pendidikan Agama Kristen, 6(2), 255-270. https://doi.org/10.30995/kur.v6i2.136

Jamhari, J. (2020). Menggagas Sosiologi Agama. Refleksi, 2(3), 5-18. https://doi.org/10.15408/ref.v2i3.14340

Larcher, F., Weisheipl, J. A., Keating, D., \& Levering, M. (2010). Commentary on the Gospel of John: Chapters 13-21. Catholic University of America Press. https://doi.org/10.2307/j.ct31nk8p

Lima, J. S. (2020). Injil Sebagai Kabar Tentang Kembalinya Kemuliaan Tuhan Ke Dalam Segenap Ciptaan. Evangelikal: Jurnal Teologi Injili dan Pembinaan Warga Jemaat, 4(1), 1-13. 
https://doi.org/10.46445/ejti.v4i1.169

Mamahit, F. Y. (2020). Sikap Ekumenikal dan Evangelikal terhadap Agama-agama Lain: Sebuah Analisis Perbandingan Historis-Teologis. DUNAMIS: Jurnal Penelitian Teologi dan Pendidikan Kristiani, 5(1), 71-92. https://doi.org/10.30648/dun.v5i1.329

Mangentang, M., \& Salurante, T. (2021). Membaca Konsep Kasih Dalam Injil Yohanes Menggunakan Lensa Hermeneutik Misional. Phronesis: Jurnal Teologi dan Misi, 4(1), 1-13. https://doi.org/10.47457/phr.v4i1.142

Manurung, K. (2020). Efektivitas Misi Penginjilan dalam Meningkatkan Pertumbuhan Gereja. DUNAMIS: Jurnal Teologi dan Pendidikan Kristiani, 4(2), 225-233. https://doi.org/10.30648/dun.v4i2.242

Marshall, I. H. (1983). Book Reviews: New Testament Background. The Expository Times, 94(4), 119-120. https://doi.org/10.1177/001452468309400419

Merwe, D. Van der. (2019). Divine Fellowship in the Gospel of John: A Trinitarian Spirituality. HTS Teologiese Studies / Theological Studies, 75(1), 1-12. https://doi.org/10.4102/hts.v75i1.5375

Muslih, M. (2017). Metodologi IImu: Dari Teori Hingga Teologi. Kalam, 7(2). https://doi.org/10.24042/klm.v7i2.456

Newbigin, L. (1993). Injil Dalam Masyarakat Majemuk. BPK Gunung Mulia.

Oet, S. (16M). Keilahian Yesus Menurut Injil Yohanes. Manna Rafflesia, 2(2), 135-147. https://doi.org/10.38091/man_raf.v2i2.61

Osborne, G. R. (2012). Spiral Hermeneutika: Pengantar Komprehensif bagi Penafsiran Alkitab (1 ed.). Momentum.

Pfitzner, V. (1988). The Gospel according to John. Lutheran Publishing House.

Rainer, A. (2012). Social History of Ancient Israel. In H. Williamson (Ed.), Understanding the History of Ancient Israel. British Academy Scholarship. https://doi.org/10.5871/bacad/9780197264010.003.0017

Raj, M., \& Seamans, R. (2019). Primer on Artificial Intelligence and Robotics. Journal of Organization Design, 8(1), 1-14. https://doi.org/10.1186/s41469-019-0050-0

Rohrbaugh, R. L. (2002). Ethnocentrism and historical questions about Jesu. In B. J. Malina \& W. Stegemann (Ed.), The social setting of Jesus and the Gospels. Fortress Press.

Sasongko, N. (2011). Menikmati Surga: Tradisi Mistik dalam Injil Tomas dan Yohanes. Veritas: Jurnal Teologi dan Pelayanan, 12(1), 109-122. https://doi.org/10.36421/veritas.v12i1.236 
Siahaan, D. S. (2017). Ketika Aku dan Kamu Menjadi Kita: Dialog Misi Penginjilan Kristen dengan Dakwah Islam Menggunakan Pendekatan Teologi Interkultural dalam Konteks Indonesia. Gema Teologika: Jurnal Teologi Kontekstual dan Filsafat Keilahian, 2(1), 41-54. https://doi.org/10.21460/gema.2017.21.280

Singgih, E. G. (2020). Agama dan Kerusakan Ekologi: Mempertimbangkan 'Tesis White' dalam Konteks Indonesia. Gema Teologika: Jurnal Teologi Kontekstual dan Filsafat Keilahian, 5(2), 113-136. https://doi.org/10.21460/gema.2020.52.614

Triasmoroadi, H. (2018). Teologi Kem(u)(a)rahan Allah: Sebuah Upaya Mengkonstruksikan Teologi Kemurahan Allah. Gema Teologika: Jurnal Teologi Kontekstual dan Filsafat Keilahian, 3(1), 39-52. https://doi.org/10.21460/gema.2018.31.318

Waharman, W. (2019). Studi Eksegetis Peranan Roh Kudus dalam Penginjilan Berdasarkan Injil Yohanes 16:4B-15. Manna Rafflesia, 6(1), 36-52. https://doi.org/10.38091/man_raf.v6i1.109 